\title{
FORMULASI TEPUNG CAMPURAN SIAP PAKAI BERBAHAN DASAR TAPIOKA-MOCAF DENGAN PENAMBAHAN MALTODEKTRIN SEBAGAI TEPUNG PELAPIS KERIPIK BAYAM
}

\author{
Abdul Razak, S.TP. ${ }^{(1)}$, dan Mulono Apriyanto, S.TP., MP ${ }^{(2)}$ \\ (1) Alumni Teknologi Pangan Faperta UNISI \\ (2) Dosen Teknologi Pangan Faperta UNISI
}

\begin{abstract}
Abstrak
Penelitian ini bertujuan untuk 1) Menentukan proporsi tepung mocaf dan tapioka yang tepat supaya menghasilkan TCSP untuk produk gorengan dengan kualitas terbaik yaitu tekstur renyah, kenampakan menarik dan kandungan minyak rendah. 2) Menentukan penambahan maltodekstrin yang tepat supaya menghasilkan TCSP untuk produk gorengan dengan kualitas terbaik yaitu tekstur renyah, kenampakan menarik dan kandungan minyak rendah. 3) Menentukan kombinasi perlakuan terbaik antara proporsi tepung mocaf dan tapioka serta penambahan maltodekstrin supaya menghasilkan TCSP untuk produk gorengan dengan kualitas terbaik yaitu tekstur renyah, kenampakan menarik dan kandungan minyak rendah.

Proporsi tapioka : tepung mocaf $=60: 40 \%$ mampu menghasilkan keripik bayam dengan tekstur renyah $(3,17)$; tepung pelapis agak rata $(1,61)$; warna putih kecokelatan $(3,39)$ dan kadar lemak 27,35 \%bk. Penambahan maltodekstrin 0,2 \% mampu menghasilkan keripik bayam dengan tekstur renyah $(2,73)$; tepung pelapis agak rata $(2,37)$; warna putih kecokelatan $(2,86)$ dan kadar lemak 31,14 \%bk. Hasil perlakuan terbaik berdasarkan uji indeks efektivitas diperoleh dari kombinasi perlakuan proporsi tapioka : tepung mocaf $=60: 40$ dan penambahan maltodekstrin 0,2 \% (T4M2). Hasil perlakuan ini memiliki kadar air TCSP 12,48 \%bb; kadar abu TCSP 2,26 \%bk; viskositas TCSP $165 \mathrm{cp}$; kapasitas penyerapan minyak TCSP 179,09 \%bk; kadar air keripik bayam 2,49 \%bb; tingkat penyerapan.
\end{abstract}

Kata Kunci : keripik bayam, mocaf, maltodektrin

\section{PENDAHULUAN}

Ilmu pengetahuan dan teknologi terus berkembang sehingga dapat mempermudah dalam menciptakan sesuatu yang baru dalam bidang pangan, salah satunya adalah produk pangan instan. Produk pangan yang dibuat instan menjadi lebih mudah dibawa dan disimpan serta praktis untuk diolah ataupun langsung dikonsumsi (Hartomo dan Widiatmoko, 1993). Salah satu produk pangan yang perlu dibuat instan adalah tepung campuran siap pakai (TCSP) untuk produk gorengan, karena sampai saat ini gorengan merupakan produk makanan yang sangat digemari oleh masyarakat dari berbagai kalangan, baik sebagai camilan maupun sebagai lauk pauk (Demedia, 2009).

Tepung campuran siap pakai yang digunakan untuk produk gorengan bisa berasal dari beberapa jenis tepung. Sebagian besar masyarakat Indonesia masih menggunakan tepung beras dan terigu sebagai bahan utama untuk membuat produk gorengan (Demedia, 2009). Pada penelitian yang telah dilakukan oleh Sutrisniati et al. (1995), 
diperoleh bahwa TCSP untuk produk gorengan (rempeyek dan keripik tempe) yang mendapatkan nilai organoleptik paling tinggi dari segi tekstur, kenampakan, warna dan rasa. Ada 2 macam yaitu TCSP yang dibuat dari campuran tepung beras 45 bagian dan pati aren 55 bagian dengan CMC 0,1\% serta campuran tepung beras 45 bagian, tapioka 55 bagian dan CMC 0,1\%.

Saat ini ketersediaan tepung beras semakin terbatas dan harga di pasaran juga meningkat tajam. Oleh karena itu, dilakukan penelitian tentang pembuatan TCSP untuk produk gorengan yang menggunakan tepung mocaf. Tepung mocaf adalah tepung dari ubi kayu (Manihot esculenta) yang diproses dengan memodifikasi sel ubi kayu secara fermentasi. Hasil penelitian sebelumnya menunjukkan bahwa tepung mocaf ini dapat dijadikan bahan baku pada beberapa jenis makanan yang terbuat dari tepung beras dan terigu seperti mie, bakery, cookies hingga makanan semi basah (Anonim, 2009).

Karakteristik tepung mocaf tidak sama persis dengan tepung terigu, beras ataupun lainnya, sehingga dalam aplikasinya diperlukan sedikit perubahan dalam formula (Faza, 2007). Untuk menghasilkan produk gorengan yang gurih dan renyah, tepung mocaf dapat dicampur dengan tapioka. Hal ini disebabkan tapioka merupakan pati yang mempunyai kandungan amilopektin lebih tinggi dari jenis pati yang lain dan memungkinkan terjadinya pengembangan yang lebih besar sehingga akan terbentuk tekstur yang lebih renyah (Muchtadi et al., 1988).

TCSP yang terbuat dari tepung mocaf selain dilakukan penambahan tapioka,perlu ditambahkan juga emulsifier. Penambahan emulsifier bertujuan agar tepung dan bumbu dapat tercampur rata pada saat diencerkan menjadi adonan. Emulsifier juga dapat meningkatkan tekstur/ kerenyahan produk gorengan yang dihasilkan. Menurut Sutrisniati et al. (1995) pada pembuatan TCSP yaitu Carboxy Methyl Cellulose (CMC). Furia (1972) menyatakan bahwa metil selulosa mempunyai fungsi menghambat proses retrogadasi dan juga berfungsi sebagai bahan pengemulsi pada adonan. Pada produk yang digoreng contohnya donat, penggunaan CMC 0,25 \% dapat mengurangi penyerapan minyak.

Emulsifier lain yang dapat diaplikasikan pada bahan makanan adalah maltodekstrin. Maltodekstrin memiliki sifat yang hampir sama dengan CMC, yaitu dapat digunakan sebagai bahan pengental dan pemantap serta mempunyai kemampuan untuk membentuk film yang stabil selama penggorengan sehingga dapat mencegah penyerapan minyak terlalu banyak yang menyebabkan produk sukar kering dan memberi rasa berminyak pada produk serta mengurangi penyerapan uap air (Whistler and Miller, 1997). Pada produk kering seperti keripik, maltodekstrin berperan dalam melapisi permukaan produk sehingga dapat mempertahankan kerenyahan ( Luthana, 2008). Oleh karena itu, penambahan maltodekstrin pada penelitian ini diharapkan juga dapat mengurangi penyerapan minyak pada produk gorengan seperti halnya CMC.

Penelitian yang telah dilakukan oleh Warsito (2003) tentang keripik bengkoang, kombinasi perlakuan terbaik didapatkan pada penyalutan dengan maltodekstrin $10 \%$ yang menghasilkan keripik bengkoang dengan tekstur paling renyah dan kadar lemak paling rendah. Penambahan maltodesktrin $4 \%$ menghasilkan seawed leather dengan tekstur mendekati kenyal (Muliani, 2005), sedangkan pada pembuatan fruit 
leather sukun penambahan maltodekstrin $2 \%$ menghasilkan tekstur agak kenyal ( Saragih, 2005).

TCSP yang terbuat dari tepung mocaf dan tapioka serta ditambah maltodekstrin sebagai emulsifier dapat digunakan untuk membuat rempeyek, keripik, ataupun produk gorengan lain yang biasanya menggunakan tepung pelapis (Sutrisniati et al., 1995). Penelitian kali ini TCSP tersebut akan diaplikasikan sebagai tepung pelapis pada keripik bayam. Pemilihan keripik bayam bertujuan untuk meningkatkan nilai ekonomis bayam serta mengenalkan keripik bayam kepada masyarakat karena selama ini masih banyak masyarakat yang belum mengenal adanya keripik bayam.

Pembuatan TCSP dari tepung mocaf dengan substitusi tapioka dan penambahan maltodekstrin akan berpengaruh terhadap sifat - sifat kimia, fisik dan sensori keripik bayam yang dihasilkan, sehingga perlu diketahui proporsi tapioka terhadap tepung mocaf dan penambahan maltodekstrin yang tepat untuk menghasilkan keripik bayam dengan kualitas yang dikehendaki yaitu renyah, kenampakan menarik dan tidak banyak mengandung minyak. Berdasarkan latar belakang di atas, maka perlu dilakukan penelitian tentang TCSP yang terbuat dari tepung mocaf dengan penambahan tapioka serta maltodekstrin sebagai emulsifier yang diaplikasikan pada keripik bayam yang berjudul "Formulasi Tepung Campuran Siap Pakai Berbahan Dasar Tapioka-Mocaf dengan Penambahan Maltodektrin Sebagai Tepung Pelapis Keripik bayam”.

\section{Perumusan Masalah}

Sebagian besar masyarakat Indonesia masih menggunakan tepung beras dan terigu. Sementara ketersediaan tepung beras semakin terbatas.
Berdasarkan hal ini dilakukan penelitian tentang TCSP untuk produk gorengan menggunakan tepung mocaf dengan judul Formulasi Tepung Campuran Siap Pakai Berbahan Dasar Tapioka-Mocaf dengan Penambahan Maltodektrin Sebagai Tepung Pelapis Keripik bayam”.

\section{Tujuan Penelitian}

Penelitian ini bertujuan untuk 1) Menentukan proporsi tepung mocaf dan tapioka yang tepat supaya menghasilkan TCSP untuk produk gorengan dengan kualitas terbaik yaitu tekstur renyah, kenampakan menarik dan kandungan minyak rendah. 2) Menentukan penambahan maltodekstrin yang tepat supaya menghasilkan TCSP untuk produk gorengan dengan kualitas terbaik yaitu tekstur renyah, kenampakan menarik dan kandungan minyak rendah. 3) Menentukan kombinasi perlakuan terbaik antara proporsi tepung mocaf dan tapioka serta penambahan maltodekstrin supaya menghasilkan TCSP untuk produk gorengan dengan kualitas terbaik yaitu tekstur renyah, kenampakan menarik dan kandungan minyak rendah.

\section{Manfaat Penelitian}

Hasil penelitian ini diharapkan dapat bermanfaat untuk :

1. Memberikan informasi bagi masyarakat untuk membuat produk gorengan menggunakan TCSP.

2. Mengurangi ketergantungan masyarakat terhadap tepung terigu dan tepung beras melalui diversifikasi bahan pangan dengan menggunakan tepung mocaf.

\section{METODOLOGI PENELITIAN}

\section{Bahan}

Bahan-bahan yang digunakan dalam penelitian ini meliputi bayam, tepung mocaf, tepung tapioka "Rose Brand", maltodekstrin yang diperoleh 
dari toko peralatan kimia dan minyak goreng "Tropical". Bumbu - bumbu yang ditambahkan yaitu garam halus, ketumbar bubuk, bawang putih bubuk dan kunyit bubuk. Bahan kimia yang digunakan untuk keperluan analisis seperti Petroleum benzen dan aquades diperoleh dari Laboratorium Teknologi Hasil Pertanian.

\section{Alat}

Peralatan yang digunakan dalam penelitian ini meliputi blender (Philips), nampan, sendok, panci, peralatan penggorengan, kompor gas, timbangan digital Ohaus (Adventurer Pro AV 412,USA), loyang, ayakan, baskom, oven (Memmert 854 Schwabach,Germany 1977), desikator, timbangan analitik (AND GR-2000,Japan 2001), viscometer (Brookfield), soklet, tanur (FurnaceThermolyne Series 1000), kompor listrik (Maspion), penangas air (Memmert $P$ Selecta Precisterm), sentrifuse (Sigma 204), tabung reaksi, rak tabung reaksi, vortex, dan gelas ukur.

\section{Metode Penelitian}

Metode penelitian yang digunakan didalam penelitian yaitu Rancangan Acak Lengkap (RAL) dengan pola faktorial yang terdiri dua faktor yaitu Faktor A adalah proporsi tapioca : tepung mocaf yang terdiri dari empat taraf yaitu :

$\mathrm{A} 1=30 \%: 70 \%$ (terdiri dari campuran tapioca $30 \%$ dani tepung mocaf $70 \%$ ). $\mathrm{A} 2=40 \%: 60 \%$ (terdiri dari campuran tapioca $40 \%$ dani tepung mocaf $60 \%$ ). $\mathrm{A} 3=50 \%: 50 \%$ (terdiri dari campuran tapioca 50\% dani tepung mocaf 50\%). A4 $=60 \%: 40 \%$ (terdiri dari campuran tapioca $60 \%$ dani tepung mocaf $30 \%$ ).

Faktor B adalah jumlah penambahan maltodekstrin yang terdiri dari empat taraf yaitu :

B0 $=0 \%$ (Perlakuan tanpa maltodektrin).

$\mathrm{B} 1=0,1 \%$ (Perlakuan dengan penambahan maltodektrin sebesar $0,1 \%$ ).

B2 $=0,2 \%$ (Perlakuan dengan penambahan maltodektrin sebesar 0,2\%).

B3 $=0,3 \%$ (Perlakuan dengan penambahan maltodektrin sebesar $0,3 \%$ ).

Dimana masing-masing perlakuan diulang sebanyak 3 kali dengan kombinasi pelakuan $4 \times 4 \times 3$ sehingga diperoleh 48 unit perlakuan.

Data yang diperoleh dari hasil penelitian dianalisis dengan menggunakan Duncan's Multiple Range Test (DMRT) pada taraf $5 \%$. Tabel kombinasi dari perlakuan dapat dilinat pada tabel 1 .

Tabel 1. Kombinasi Perlakuan

\begin{tabular}{|c|c|c|c|c|}
\hline \multirow{2}{*}{ B } & \multicolumn{4}{|c|}{ A } \\
\cline { 2 - 5 } & A1 & A2 & A3 & A4 \\
\hline B0 & B0A1(3X) & B0A2(3X) & B0A3(3X) & B0A4(3X) \\
\hline B1 & B1A1(3X) & B1A2(3X) & B1A3(3X) & B1A4(3X) \\
\hline B2 & B2A1(3X) & B2A2(3X) & B2A3(3X) & B2A4(3X) \\
\hline B3 & B3A1(3X) & B3A2(3X) & B3A3(3X) & B3A4(3X) \\
\hline
\end{tabular}

\section{Pelaksanaan Penelitian}

\section{Penelitian pendahuluan}

Penelitian pendahuluan dilakukan untuk menentukan proporsi tapioka dan tepung mocaf yang akan dipakai dalam penelitian lanjutan. Selain itu pada penelitian pendahuluan juga ditentukan persentase maltodekstrin yang cocok untuk ditambahkan, jumlah air yang tepat untuk ditambahkan, serta waktu dan suhu penggorengan yang tepat. Pada 
penelitian pendahuluan ini tepung campuran dicoba untuk diaplikasikan pada pembuatan keripik bayam. Perlakuan yang dapat digunakan untuk penelitian lanjutan adalah perlakuan yang menghasilkan keripik bayam yang kualitas sensorinya dapat diterima dari segi kenampakan, tekstur/kerenyahan dan rasa.

Perbandingan antara tapioka dengan tepung mocaf yang dicoba pada penelitian pendahuluan yaitu 30:70, 40:60, 50:50, 60:40 dan 70:30\% (b/b). Untuk tapioka $:$ mocaf $=20: 80 \%$ tidak digunakan pada penelitian ini karena adonan terlalu kental dan pada penggorengan dengan suhu $170^{\circ} \mathrm{C}$ dengan waktu 1 menit keripik bayam yang dihasilkan kenampakan tepungnya terlalu tebal sehingga teksturnyapun tidak renyah. Jika waktu penggorengan ditambah menjadi jadi 2 menit keripik bayam menjadi gosong. Begitu pula dengan tapioka $:$ mocaf $=80: 20 \%$ tidak dipakai karena adonan terlalu encer dan pada waktu dan suhu penggorengan yang sama, keripik bayam yang dihasilkan kenampakan tidak rata dan banyak porous, teksturnyapun sangat keras. Untuk perbandingan tapioka : mocaf $=$ $30: 70 \%, 40: 60 \%, 50: 50 \%$, dan 60 : $40 \%$, keripik bayam yang dihasilkan kenampakan tepung rata dan putih sehingga menarik, tekstur renyah dan tidak keras, rasa keripik juga enak. Sedangkan tapioka : mocaf $=70: 30 \%$ hasilnya sama dengan tapioka : mocaf $=$ 80 : 20\%, sehingga proporsi tersebut tidak diterima. Jadi proporsi antara tapioka dengan tepung mocaf yang akan digunakan untuk penelitian lanjutan adalah $30: 70 \%, 40: 60 \%, 50: 50 \%$, dan $60: 40 \%(\mathrm{~b} / \mathrm{b})$.

Konsentrasi maltodekstrin yang dicoba pada penelitian pendahuluan yang telah dilakukan yaitu $0 \% ; 0,05 \%$; dan $0,3 \%$ (Nurhayati, 2003). Untuk maltodekstrin 0\% keripik bayam yang dihasilkan kenampakan tepung kurang rata dan sangat berminyak teksturnya juga kurang renyah. Meskipun demikian maltodekstrin $0 \%$ ini tetap digunakan pada penelitian lanjutan sebagai kontrol. Sedangkan pada maltodekstrin 0,05\% keripik bayam yang dihasilkan tidak berbeda dengan keripik bayam tanpa maltodekstrin yaitu kenampakan tepung kurang rata dan sangat berminyak teksturnya juga kurang renyah. Maltodekstrin $\quad 0,3 \%$ menghasilkan keripik bayam dengan tekstur yang keras namun kenampakan tepungnya tetap rata dan agak berminyak, sehingga masih dapat diterima. Jadi konsentrasi maltodekstrin yang akan digunakan untuk penelitian lanjutan adalah $0 \%$; $0,1 \% ; 0,2 \%$ dan $0,3 \%$.

Perbandingan antara tepung dan air yang dicoba adalah $1: 1,1: 2$ dan 1:3 (b/v). Untuk perbandingan $1: 1$ adonan pada proporsi tapioka : mocaf $=30: 70$ terlalu kental, sedangkan perbandingan 1 : 3, adonan pada proporsi tapioka : mocaf $=60: 40$ terlalu encer. Perbandingan $1: 2$ menghasilkan adonan untuk proporsi tapioka : mocaf $=30: 70$ yang tidak terlalu kental dan untuk tapioka : mocaf $=60: 40$ tidak terlalu encer. Sehingga perbandingan antara tepung dan air yang akan digunakan pada penelitian lanjutan adalah $1: 2$ $(\mathrm{b} / \mathrm{v})$.

Suhu penggorengan yang dipakai mengacu pada penelitian-penelitian terdahulu dimana untuk menggoreng keripik tempe, suhu yang dipakai berkisar antara $160^{\circ}-170^{\circ} \mathrm{C}$. Sehingga pada pembuatan keripik bayam kali ini dicoba suhu penggorengan $160^{\circ}$, dan ternyata pada suhu tersebut keripik bayam yang dihasilkan kenampakan dan teksturnya dapat diterima. Oleh karena itu pada penelitian lanjutan, suhu 
penggorengan yang dipakai adalah $160^{\circ} \mathrm{C}$.

Waktu penggorengan yang dicoba pada penelitian ini yaitu 60, 90 dan 120 detik. Pada waktu 60 detik keripik bayam yang dihasilkan tekstur kurang renyah, sedangkan pada waktu 120 detik keripik bayam yang dihasilkan gosong. Pada waktu 90 detik keripik bayam yang dihasilkan tekstur renyah dan kenampakannya pun masih putih tidak gosong. Sehingga waktu penggorengan yang dipakai pada penelitian ini adalah 90 detik.

\section{Penelitian Utama}

Tahap-tahap yang dilakukan dalam penelitian utama yaitu yang pertama pembuatan tepung campuran siap pakai. Tepung mocaf dicampur dengan tapioka dimana proporsi/perbandingannya berdasarkan hasil penelitian pendahuluan yang telah dilakukan. Kemudian tepung tersebut dicampur maltodekstrin dengan konsentrasi berdasarkan hasil penelitian pendahuluan yang telah dilakukan.

Bumbu - bumbu yang ditambahkan pada proses pembuatan tepung campuran siap pakai meliputi garam halus 2,25\%, ketumbar bubuk $2 \%$, bawang putih bubuk $2 \%$, dan kunyit bubuk 0,01\%.

Penentuan jenis dan banyaknya bumbu tersebut disesuaikan dengan penelitian yang telah dilakukan oleh Sutrisniati et al. (1995) pada pembuatan tepung campuran siap pakai untuk produk gorengan. Setelah dilakukan pengayakan, tepung campuran siap pakai kemudian dianalisis secara kimia maupun fisik. Tepung campuran siap pakai kemudian diaplikasikan sebagai tepung pelapis pada keripik bayam. Keripik bayam yang dihasilkan selanjutnya digunakan untuk analisis penyerapan minyak, kadar air serta analisis sensoris.

\section{Kadar air TCSP}

Proporsi tapioka : mocaf (A) berpengaruh sangat nyata terhadap kadar air TCSP (\%). Kadar air TCSP pada proporsi tapioka : mocaf $(\mathrm{A})=30: 70 \%$ (A1); 40:60\% (A2); 50:50\% (A3) dan 60:40\% (A4) berturut-turut adalah 11,21 $\%$ bb; 12,14 \%bb; 14,13 \%bb dan 15,22 \%bb. Kadar air pada berbagai persentase proporsi TCSP dapat dilihat pada tabel 7.

Tabel 7. Pengaruh (A) proporsi tepung tapioka : tepung mocaf terhadap Kadar Air $\operatorname{TCSP}(\%)$

\begin{tabular}{|l|l|}
\hline \multicolumn{1}{|c|}{ Perlakuan } & \multicolumn{1}{|c|}{ Kadar Air TCSP (\%) } \\
\hline A4 & $15.219 \mathrm{a}$ \\
A3 & $14.126 \mathrm{~b}$ \\
A2 & $12.135 \mathrm{c}$ \\
A1 & $11.197 \mathrm{~d}$ \\
\hline
\end{tabular}

Keterangan : Angka-angka pada jalur yang sama diikuti oleh huruf kecil yang sama menunjukan berbeda tidak nyata pada taraf $5 \%$

Penambahan konsentrasi maltodekstrin (B) berpengaruh sangat nyata terhadap kadar air. Kadar air TCSP pada penambahan maltodektrin (B) adalah tanpa penambahan maltodektrin
(B0), 0,1\% (B1), 0,2\% (B2), 0,3\%(B3), berturut - turut nilainya $11,398 \%$, $12,657 \%, 13,530 \%$ dan $15,091 \%$. 
Tabel 8. Pengaruh (B) penambahan Maltodektrin terhadap Kadar Air TCSP (\%)

\begin{tabular}{|l|l|}
\hline Perlakuan & Kadar Air TCSP (\%) \\
\hline B3 & $15.091 \mathrm{a}$ \\
B2 & $13.530 \mathrm{~b}$ \\
B1 & $12.657 \mathrm{c}$ \\
B0 & $11.398 \mathrm{~d}$ \\
\hline
\end{tabular}

Keterangan : Angka-angka pada jalur yang sama diikuti oleh huruf kecil yang sama menunjukan berbeda tidak nyata pada taraf $5 \%$

$\begin{array}{lll}\text { Menurut Sudarmadji } & (1984), & \text { yang cukup lama karena lebih cepat } \\ \text { bahwa besarnya kadar air TCSP } & \text { rusak akibat ditumbuhi jamur sehingga } \\ \text { berhubungan dengan daya tahan tepung } & \text { kualitas menjadi menurun. Berdasarkan } \\ \text { selama penyimpanan. Air yang terdapat } & \text { SNI 01-4476-1998 kadar air maksimal } \\ \text { dalam bentuk bebas pada bahan pangan } & \text { untuk tepung bumbu yaitu 12\%. } \\ \text { dapat membantu terjadinya proses } & \text { Interakasi pengaruh proporsi } \\ \text { kerusakan pangan, misalnya karena } & \text { tepung tapioca : tepung mocaf dan } \\ \text { proses mikrobiologis, kimiawi, enzimatis } & \text { penambahan maltodektrin terhadap } \\ \text { bahkan karena aktivitas serangga } & \text { kadar air TCSP tersaji pada tabel 9. }\end{array}$
perusak. Kadar air tinggi menyebabkan tepung tidak tahan simpan dalam waktu

Tabel 9. Interaksi proporsi tepung tapioca : tepung mocaf dan penambahan maltodektrin terhadap kadar air TCSP $(\%)$.

\begin{tabular}{|l|l|}
\hline \multicolumn{1}{|c|}{ Perlakuan } & \multicolumn{1}{|c|}{ Kadar Air TCSP (\%) } \\
\hline A4B3 & $18.167 \mathrm{a}$ \\
A3B3 & $16.523 \mathrm{~b}$ \\
A4B2 & $16.523 \mathrm{~b}$ \\
A3B2 & $14.613 \mathrm{~d}$ \\
A4B1 & $14.373 \mathrm{~d}$ \\
A2B3 & $13.577 \mathrm{e}$ \\
A3B1 & $13.457 \mathrm{e}$ \\
A4B0 & $12.497 \mathrm{f}$ \\
A2B2 & $12.267 \mathrm{fg}$ \\
A1B3 & $12.097 \mathrm{fg}$ \\
A3B0 & $11.910 \mathrm{~g}$ \\
A2B1 & $11.870 \mathrm{~g}$ \\
A1B2 & $11.400 \mathrm{~h}$ \\
A1B1 & $10.930 \mathrm{i}$ \\
A2B0 & $10.827 \mathrm{i}$ \\
A1B0 & $10.360 \mathrm{j}$ \\
\hline
\end{tabular}

\section{Kadar Abu TCSP}

Proporsi tapioka : mocaf (A) berpengaruh sangat nyata terhadap kadar abu TCSP begitu juga pada konsentrasi maltodekstrin (B) dan interaksinya berpengaruh sangat nyata. Kadar abu
TCSP pada proporsi tapioka : mocaf (A) $=30: 70 \%$ (A1); 40:60\% (A2); 50:50\% (A3) dan 60:40\% (A4) berturut-turut adalah 3,31 \%bk; 3,03 \%bk; 2,62 \%bk dan 2,01 \%bk. Kadar air pada berbagai 
persentase proporsi TCSP dapat dilihat pada tabel 10.

Tabel 10. Pengaruh (A) proporsi tepung tapioka : tepung mocaf terhadap Kadar Abu (\%)

\begin{tabular}{|l|l|}
\hline \multicolumn{1}{|c|}{ Perlakuan } & \multicolumn{1}{|c|}{ Kadar Abu TCSP (\%) } \\
\hline A1 & $3.3100 \mathrm{a}$ \\
A2 & $3.0250 \mathrm{~b}$ \\
A3 & $2.6167 \mathrm{c}$ \\
A4 & $2.0067 \mathrm{~d}$ \\
\hline
\end{tabular}

Keterangan : Angka-angka pada jalur yang sama diikuti oleh huruf kecil yang sama menunjukan berbeda tidak nyata pada taraf $5 \%$

Semakin banyak proporsi tapioka maka kadar abu tepung campuran juga semakin menurun. Hal ini disebabkan tepung mocaf mengandung kadar abu yang lebih tinggi yaitu 0,2 \% (Faza, 2007) dibandingkan dengan kadar abu dari tapioka yang hanya $0,06 \%$ (De Man, 1997). Tepung mengandung berbagai macam mineral seperti kalsium, besi dan phospor. Pada tapioka, mineral yang ada di dalamnya jumlahnya sangat sedikit karena hampir seluruh komponen penyusunnya adalah pati. Kadar abu TCSP pada berbagai konsentrasi maltodekstrin dapat dilihat pada tabel 11.

Tabel 11. Pengaruh (B) penambahan Maltodektrin terhadap Kadar Abu (\%)

\begin{tabular}{|l|l|}
\hline Perlakuan & Kadar Abu (\%) \\
\hline B3 & $3.1075 \mathrm{a}$ \\
B2 & $2.7233 \mathrm{~b}$ \\
B1 & $2.5658 \mathrm{c}$ \\
B0 & $2.5617 \mathrm{c}$ \\
\hline
\end{tabular}

Keterangan : Angka-angka pada jalur yang sama diikuti oleh huruf kecil yang sama menunjukan berbeda tidak nyata pada taraf $5 \%$

Kadar abu TCSP pada konsentrasi maltodekstrin $0 \% \quad(\mathrm{~B} 0)$; $0,1 \%$ (B1); $0,2 \%$ (B2) dan $0,3 \%$ (B3) berturut-turut adalah $2.562 \% ; 2.566 \%$; $2.723 \%$ dan $3.108 \%$. Proporsi tapioka : mocaf $=60: 40 \%$ memiliki kadar abu yang terendah yaitu sebesar 2,01 \%bk. Interakasi pengaruh proporsi tepung tapioca : tepung mocaf dan penambahan maltodektrin terhadap kadar abu tersaji pada tabel 12.

Namun kadar abu tersebut masih melebihi batas maksimal. Berdasarkan
SNI 01-2997-1992 kadar abu maksimal untuk tepung adalah 1,52 \%bk.

Tapioka merupakan hasil ekstraksi dari ubi kayu yang dalam proses pembuatannya dilakukan pemurnian, sehingga komponen komponen selain pati tidak ada (Tjokroadikoesomo, 1986). Kadar abu yang tinggi pada tepung dapat menurunkan kualitas TCSP dan keripik yang dihasilkan karena dapat menyebabkan warna tepung dan keripik bayam menjadi lebih gelap (Rustandi, 2009). 
Tabel 12. Interaksi proporsi tepung tapioca : tepung mocaf dan penambahan maltodektrin terhadap kadar abu (\%).

\begin{tabular}{|l|l|}
\hline \multicolumn{1}{|c|}{ Perlakuan } & \multicolumn{1}{c|}{ Kadar Abu } \\
\hline A1B3 & $3.8600 \mathrm{a}$ \\
A2B3 & $3.6200 \mathrm{~b}$ \\
A1B2 & $3.2133 \mathrm{c}$ \\
A1B1 & $3.1467 \mathrm{c}$ \\
A2B2 & $3.0267 \mathrm{~d}$ \\
A1B0 & $3.0200 \mathrm{~d}$ \\
A3B3 & $2.8200 \mathrm{e}$ \\
A2B0 & $2.7600 \mathrm{ef}$ \\
A2B1 & $2.6933 \mathrm{fg}$ \\
A3B2 & $2.6667 \mathrm{~g}$ \\
A3B1 & $2.5433 \mathrm{~h}$ \\
A3B0 & $2.4367 \mathrm{i}$ \\
A4B3 & $2.1300 \mathrm{j}$ \\
A4B0 & $2.0300 \mathrm{k}$ \\
A4B2 & $1.9867 \mathrm{k}$ \\
A4B1 & $1.8800 \mathrm{l}$ \\
\hline
\end{tabular}

Keterangan : Angka-angka pada jalur yang sama diikuti oleh huruf kecil yang sama menunjukan berbeda tidak nyata pada taraf $5 \%$

\section{Viskositas TCSP}

Hasil analisis ragam menunjukkan bahwa proporsi tapioka : mocaf (A) dan konsentrasi maltodekstrin (B) berpengaruh sangat nyata terhadap viskositas TCSP sedangkan interaksinya tidak berpengaruh nyata. Viskositas TCSP pada proporsi tapioka : mocaf (A)
$=30: 70 \%$ (A1); 40:60\% (A2); 50:50\% (A3) dan 60:40\% (A4) berturut-turut adalah $217,50 \mathrm{cp} ; 188,10 \mathrm{cp} ; 164,40 \mathrm{cp}$ dan $152,50 \mathrm{cp}$.

Pengaruh proporsi tepung tapioca : tepung mocaf terhadap viskositas dapat dilihat pada tabel 13 .

Tabel 13. Pengaruh (A) proporsi tepung tapioka : tepung mocaf terhadap Viscositas

\begin{tabular}{|c|c|}
\hline Perlakuan & Viscositas (cp) \\
\hline A1 & $241.47 \mathrm{a}$ \\
\hline $\mathrm{A} 2$ & $141.01 \mathrm{~b}$ \\
\hline A3 & $107.86 \mathrm{c}$ \\
\hline A4 & $102.11 \mathrm{~d}$ \\
\hline
\end{tabular}

Keterangan : Angka-angka pada jalur yang sama diikuti oleh huruf kecil yang sama menunjukan berbeda tidak nyata pada taraf $5 \%$

Semakin kecil proporsi tepung mocaf maka viskositas TCSP semakin menurun. Hal ini disebabkan viskositas berkaitan dengan proses gelatinisasi dan tingkat penyerapan air. Faktor-faktor yang berpengaruh terhadap viskositas antara lain sifat alami dari pati itu sendiri (telah tergelatinisasi sempurna atau belum) dan proporsi amilosa dan amilopektin yang ada pada pati. Viskositas TCSP pada konsentrasi maltodekstrin $0 \%$ (B0); 0,1\% (B1); 0,2\% (B2) dan 0,3\% (B3) berturut-turut adalah $135,05 \mathrm{cp} ; 136,65 \mathrm{cp} ; 136.84 \mathrm{cp}$ dan 
184.22 cp. Viskositas TCSP pada dapat dilihat pada tabel 14. berbagai penambahan maltodekstrin

Tabel 14. Pengaruh (B) penambahan Maltodektrin terhadap Viscositas (cp)

\begin{tabular}{|l|l|}
\hline \multicolumn{1}{|c|}{ Perlakuan } & \multicolumn{1}{c|}{ Viscositas (cp) } \\
\hline B3 & $184.22 \mathrm{a}$ \\
B2 & $136.84 \mathrm{~b}$ \\
B1 & $136.35 \mathrm{c}$ \\
B0 & $135.05 \mathrm{~d}$ \\
\hline
\end{tabular}

Keterangan : Angka-angka pada jalur yang sama diikuti oleh huruf kecil yang sama menunjukan berbeda tidak nyata pada taraf $5 \%$

Menurut Rahman (2007) kandungan pati dari tepung mocaf 73,29 $\%$ bk, sedangkan kandungan pati pada tapioka 86,90 \%bk (Suprapti, 2009). Jumlah gugus hidroksil dalam molekul pati sangat besar, sehingga semakin besar proporsi tapioka maka kemampuan menyerap air semakin besar pula. Meningkatnya viskositas dimulai pada saat granula-granula pati mulai membengkak. Air yang semula berada di luar granula dan bergerak bebas sebelum suspensi dipanaskan, kini sudah berada di dalam butir-butir pati dan tidak dapat bergerak dengan bebas lagi (Winarno, 1992). Faktor-faktor yang berpengaruh terhadap kenaikan penyerapan air secara tidak langsung juga akan berpengaruh terhadap kenaikan viskositas (Whistler and Paschall, 1969) maka semakin tinggi kadar pati, penyerapan air semakin besar sehingga viskositas semakin meningkat. Hal ini karena maltodekstrin mempunyai viskositas yang relatif tinggi. Maltodekstrin juga bersifat humektan yaitu dapat mengikat air sehingga dapat digunakan dalam mengatur viskositas suatu produk sesuai yang diinginkan (Whistler et al., 1984). Interakasi pengaruh proporsi tepung tapioca : tepung mocaf dan penambahan maltodektrin terhadap kadar abu tersaji pada tabel 15 .

Menurut dari tabel dan grafik proporsi amilosa yang semakin tinggi menyebabkan kekentalan produk semakin rendah (Laga, 2006). Menurut Rahman (2007) kandungan amilosa pada tepung mocaf yaitu 11,07 \%bk, sedangkan pada tapioka 17,39 \%bk sehingga semakin tinggi proporsi tapioka pada TCSP, viskositasnya semakin rendah. Pati dengan kadar amilosa tinggi akan menyebabkan lapisan (film) menjadi rapat akibat terjadinya interaksi antara rantai (chain-to-chain) molekul polimer yang lebih kuat sehingga sifat hidrofilik lapisan (film) menjadi menurun karena mengandung sedikit gugus hidroksil (Garcia et. al., 1999 dalam Cahyana dan Haryanto, 2006).

Amilopektin berperan dalam memerangkap air yang mempengaruhi viskositas menjadi semakin tinggi. Amilopektin merupakan penyusun pati yang tersusun dari monomer $\alpha$-glukosa yang terikat dengan ikatan 1,4-glikosidik dengan terbentuk cabang-cabang (tiap 20 mata rantai glukosa) dengan ikatan 1,6glikosidik. Adanya rantai cabang, mengakibatkan amilopektin memiliki sifat amorf sehingga lebih renggang dan air lebih mudah masuk. Hal ini menyebabkan gelatinisasi dan pengembangan bahan berjalan lebih sempurna, sehingga viskositas meningkat. 
Tabel 15. Interaksi proporsi tepung tapioca : tepung mocaf dan penambahan maltodektrin terhadap Viscositas (cp).

\begin{tabular}{|l|l|}
\hline \multicolumn{1}{|c|}{ Perlakuan } & \multicolumn{1}{c|}{ Viscositas (cp) } \\
\hline A1B3 & $312.03 \mathrm{a}$ \\
A1B1 & $218.65 \mathrm{~b}$ \\
A1B2 & $218.45 \mathrm{c}$ \\
A1B0 & $216.77 \mathrm{~d}$ \\
A2B3 & $211.46 \mathrm{e}$ \\
A2B2 & $118.21 \mathrm{f}$ \\
A2B1 & $117.87 \mathrm{~g}$ \\
A2B0 & $116.51 \mathrm{~h}$ \\
A3B3 & $110.35 \mathrm{i}$ \\
A3B2 & $108.06 \mathrm{j}$ \\
A3B1 & $107.02 \mathrm{k}$ \\
A3B0 & $106.02 \mathrm{l}$ \\
A4B3 & $103.03 \mathrm{~m}$ \\
A4B2 & $102.66 \mathrm{n}$ \\
A4B1 & $101.87 \mathrm{o}$ \\
A4B0 & $100.89 \mathrm{p}$ \\
\hline
\end{tabular}

Keterangan : Angka-angka pada jalur yang sama diikuti oleh huruf kecil yang sama menunjukan berbeda tidak nyata pada taraf 5\%

\section{KESIMPULAN DAN SARAN}

\section{Kesimpulan}

1. Proporsi tapioka : tepung mocaf $=$ 60 : $40 \%$ mampu menghasilkan keripik bayam dengan tekstur renyah $(3,17)$; tepung pelapis agak rata $(1,61)$; warna putih kecokelatan $(3,39)$ dan kadar lemak 27,35 \%bk.

2. Penambahan maltodekstrin $0,2 \%$ mampu menghasilkan keripik bayam dengan tekstur renyah $(2,73)$; tepung pelapis agak rata $(2,37)$; warna putih kecokelatan $(2,86)$ dan kadar lemak 31,14 \%bk.

3. Hasil perlakuan terbaik berdasarkan uji indeks efektivitas diperoleh dari kombinasi perlakuan proporsi tapioka : tepung mocaf $=60: 40$ dan penambahan maltodekstrin 0,2 $\%$ (T4M2). Hasil perlakuan ini memiliki kadar air TCSP 12,48 \%bb; kadar abu TCSP 2,26 \%bk; viskositas TCSP $165 \mathrm{cp}$; kapasitas penyerapan minyak TCSP 179,09 \%bk; kadar air keripik bayam 2,49

\%bb; tingkat penyerapan.

\section{Saran}

Perbandingan tepung campuran siap pakai dan tepung mocaf menjadikan hasil adonan yang menentukan tingkat kerenyahan produk kripik bayam disamping sehingga perlu dilakukan penelitian lebih lanjut tentang formulasi yang tepat terhadap bahan baku lainnya. Persentase penambahan maltodektrin akan berakibat pada pencoklatan bahan yang ini akan berpengaruh kepada penerimaan terhadap keripik bayam sehingga perlu juga dilakukan penelitian lebih lanjut pada perbandingan yang lain.

\section{DAFTAR PUSTAKA}

Blanchard, P.H. and R.K. Franches. 1995. Starch : Chemistry and Technology. Academic Press Inc, New York. 718pp. 
De Man, J.M. 1997. Kimia Makanan. Penerbit ITB, Bandung.

Demedia. 2009. Rahasia Membuat Gorengan Terbaik. (On-Line) http://demediapustaka.com.

Diakses pada tanggal 1 November 2009

Direktorat Depkes RI. 1990. Daftar Konsumsi Bahan Makanan. Bharata Karya Aksara, Jakarta.

Faza, F. 2007. Kurangi Impor Terigu Dengan Mocaf.(On-Line) http://agrina-nline.com. Diakses pada tanggal 25 November 2009.

Fellow, J.J. 1990. Food Processing Technology, Principle and Practise. Ellis Horwood. London.

Furia, T.E.1972. Handbook of Food Additive, Vol.I,2nd ed. Cleveland, CRC.

Harris, R.S. dan E.Karmas. 1975. Evaluasi gizi pada pengolahan bahan pangan. ITB Press. Bandung.

Hartomo, A.J. dan M.C. Widiatmoko. 1993. Emulsi dan Pangan Instan Berlesitin. Penerbit Andi Offset. Yogyakarta.

Haryadi. 1990. Pengaruh Kadar Amilosa Beberapa Jenis Pati Terhadap Pengembangan, Higroskopisitas dan Sifat Inderawi Kerupuk. Laporan Penelitian. UGM, Yogyakarta.

(Tidak dipublikasikan).

Herlina, L. 1999. Peran Tepung Kedelai, Tahu dan Variasi Pengenceran Tepung Adonan Tempe Chips Dalam Upaya Pengurangan Absorbsi Minyak Goreng. Skripsi. Fakultas Pertanian UNSOED, Purwokerto.

(Tidak dipublikasikan).

Kadan, R.S., R.J. Bryant and A.B. Pepperman. 2003. Functional properties of extruded rice flours. J. Food Sci., 68:1669-1672.
Ketaren, S. 1986. Pengantar Teknologi Minyak dan Lemak Pangan. UI Press. Jakarta.

Laga, A. 2006. Pengembangan Pati Termodifikasi dari Subtrat Tapioka dengan Optimalisasi Pemotongan Rantai Cabang Menggunakan Enzim Pullunase. Prosiding Seminar Nasional PATPI, 2-3 Agustus 2006, Perhimpunan Ahli Teknologi Pangan Indonesia (PATPI).

Lawson, H. 1994. Food Oils and Fats, Technology Utilizationa and Nutrition. Chapman and Hall Dept. B,C. New York.

Matz, S.A. 1976. Snack Food Technology. AVI. Westport.

Muliani, R.R.D. 2005. Penambahan Jambu Biji sebagai Flavoran dan Maltodesktrin terhadap Sifat Kimia dan Sensorik Seawed Leather. Skripsi. Fakultas Pertanian Unsoed, Purwokerto. (Tidak dipublikasikan).

Nurhayati. 2003. Studi Penggorengan Keripik Sayuran Menggunakan Tapioka Sebagai Tepung Pelapis. Tesis Universitas Brawijaya Malang. Malang.

Oey, K.N. 1998. Daftar Analisa Bahan Makanan. Penerbit FKUI, Jakarta.

Rahman, A.M. 2007. Mempelajari Karakteristik Kimia dan Fisik Tepung Tapioka dan Mocaf (Modified Cassava Flour) Sebagai Penyalut Kacang Pada Produk Kacang Salut. Skripsi. Fakultas Teknologi Pertanian, IPB. Bogor. (Tidak dipublikasikan).

Ramdhan, A.N. 2009. Pengaruh Perbandingan Tepung Beras Rose Brand, Tepung Beras Karya Tani dan Konsentrasi Santan Kelapa Terhadap Karakteristik Rempeyek Bayam. Kumpulan Program 
Kreatifitas Mahasiswa. Unpas. Bandung.

Soeparno. 1992. Ilmu dan Teknologi Daging. Gajah Mada Univercity Press. Yogyakarta

Subagio, A. 2007. Industrialisasi Modified Cassava Flour (Mocaf) Sebagai Bahan Baku Industri Pangan Untuk Menunjang Diversifikasi Pangan Pokok Nasional.Fakultas Teknologi Pertanian, Universitas Jember. Jember.

Sudarmadji, S. 1996. Analisa Bahan Makanan dan Pertanian. Penerbit Liberty. Jogjakarta.

Sumaryono, H. 1984. Kunci Bercocok Tanam Sayur-Sayuran Penting di Indonesia. CV Sinar Baru. Bandung

Suprapti, M.L. 2009. Tepung Tapioka Pembuatan dan Pemanfaatannya. Penerbit Kanisius. Yogyakarta.

Sutrisniati, D; D. Mahdar; H. Wiriano dan I.N. Ridwan. 1995. Pengaruh pencampuran tepung dan penambahan carboxy methyl cellulose (CMC) pada pembuatan tepung campuran siap pakai untuk produk gorengan. Jurnal Warta IHP. 12(1-2):1-4.

Tranggono. 1990. Bahan Tambahan Pangan (Food Additive). PAU Pangan dan Gizi. UGM, Yogyakarta.

Tursilawati, R.A. 1999. Pengurangan Absorbsi Minyak Pada Pembuatan Tempe Chip : Pengaruh Penggunaan Carboxy Methyl Cellulose (CMC) dan Pengenceran
Adonan Tepung Pelapis. Skripsi. Fakultas Pertanian UNSOED. Purwokerto.

(Tidak dipublikasikan).

Vail, G.E.; J.A. Philips, L.O. Rust, R.M. Griswood and M.M. Justin. 1988. Foods. Houtson Mifllin Company, Boston.

Voutsinas, L.P. and Nakai, S. 1983. A simple turbidimetric method for determining the fat binding capacity of proteins. Journal Agri. Food Chem. 31 : 58-61.

Weiss, T.J. 1983. Food Oils and Their Uses. The AVI Publishing Co.,Inc. Westport. Connecticut.

Whistler, F.R., J.N. Be Miller and E.F. Paschall. 1984. Carbohydrate Chemistry for Food Scientist. Academica, Inc. London.

Whistler, F.R. and J.N. Be Miller. 1997. Carbohydrate Chemistry for Food Scientist. Academica, Inc. London.

Whistler, R.L dan E.P. Paschall. 1969. In Starch Chemistry and Tech. Academic Press, New York Vol 1.

Widowati, S; Suismono; Suarni; Sutrisno dan O. Komalasari. 2002. Petunjuk Teknis : Proses Pembuatan Aneka Tepung Dari Bahan Sumber Karbohidrat Local. Balai Penelitian Pascapanen Pertanian. Badan Litbang Pertanian.

Winarno, F.G. dan S.T. Rahayu. 1994. Bahan Tambahan Makanan dan Kontaminan. Pustaka Sinar Harapan, Jakarta.

Winarno, F.G. 1997. Kimia Pangan dan Gizi. PT Gramedia Pustaka Utama. Jakarta. 